\title{
KONFLIK BATIN TERKAIT SIKAP AYAH TERHADAP ANAK PADA NOVEL PENARI KECIL KARYA SARI SAFITRI MOHAN
}

\author{
Enik Fuji Asrini, M. Shoim Anwar \\ (Pendidikan Bahasa dan Sastra Indonesia, Fakultas Keguruan dan Imu Pendidikan, \\ Universitas PGRI Adi Buana Surabaya) \\ enikfuji@gmail.com, shoimanwar@yahoo.com
}

\begin{abstract}
ABSTRAK
Psikologi adalah ilmu yang mempelajari dan mempelajari suatu perilaku kemanusiaan dan psikologi untuk menjelaskan bahwa teori kepribadian yang dijelaskan psikologi sastra adalah id, emosi dan superemosi, ide adalah subjek realitas primer, sedangkan emosi untuk tujuan mengendalikan suatu ide dan kata superemosi. Itulah tujuan penelitian ini untuk mengetahui konflik antara anak dan ayah dalam novel penari kecil karya Sari Safitri Mohan. Dalam penelitian ini kami menggunakan teknik pengambilan sampel data dan data yang kami gunakan adalah dokumentasi dari mulai membaca novel sampai pencarian mengumpulkan data pada konflik terkait dan psikologi sedangkan pencarian data menggunakan metad guaura dan deskripsi lima berdasarkan data pencarian kami yakin bahwa ayahnya selalu tepat. Hingga semua gadisnya mengalami tekanan dan berujung pada tindakan tak terduga saat novel penari kecil menunjukkan egoisme orang tua untuk pendidikan yang baik bagi anaknya. Semua anak berada di bawah tekanan untuk semua aturan dan larangan di rumah, semua yang mereka lakukan harus izin kepada ayahnya berarti sementara ada kesenangan yang dia sia-siakan. Intan putra pertamanya atau Ibrahim dia mengalami tekanan dan paksaan dalam-dalam hingga perkembangan psikologi anak. Kesimpulan selanjutnya mengarah pada anak kedua Ibrahim (Ira), Ira memiliki pengalaman yang sama seperti Intan yaitu band yang tidak wajar bagi ayahnya untuk Ira seperti, jam pulang untuk Ira, membuat Ira ke fakultas ekonomi dan setengah senang bund ini di buat Ira depresi menyebabkan kecemasan dan ketidaknyamanan.
\end{abstract}

Kata Kunci: Konflik, Psikologi, Konflik Batin

\section{PENDAHULUAN}

Novel sudah tidak asing lagi bagi orang-orang yang suka membaca. Banyak cerita di dalam nya yang inspiratif, bacaannya yang ringan, asyik dan menambah wawasan, sehingga novel banyak digemari oleh sebagian orang, bahkan novel banyak dijadikan sebagai bacaan terfavorit bagi semua kalangan. karya sastra dalam novel ini tidak terlepas dari konflik yang melibatkan psikologi sastra sebagai pendekatannya. Konflik yang terdapat pada novel Penar Kecil ini, menggambarkan pandangan hidup pengarang yang ingin disampaikan kepada pembacanya. Latar belakang peneliti memilih judul konflik batin terhadap sikap ayah terhadap anak pada novel penari kecil karya sari safitri mohan peneliti banyak menemukan berbagai macam konflik yang terjadi dalam rangkaian kisah para tokoh dalam novel tersebut. Di dalam novel itu terdapat tekanan batin yang menarik dan perlu dianalisis dalam berbagai persoalan tentang kehidupan dan pengorbanan seorang ayah kepada anak, dan anaknya kepada ayah. Isi novel yang terkait dengan psikologi sastra yang perlu dianalisis untuk dapat dijadikan pembelajaran agar lebih baik. 
Alasan peneliti memilih pengarang Sari Safitri Mohan daripada pengarang lain. Karena Sari Safitri Mohan banyak mendeskripsikan dan mengungkapkan sesuatu dalam bentuk kalimat yang membuat peneliti terkesima dan kagum. Bahasa yang digunakan oleh Sari Safitri Mohan menggunakan bahasa Indonesia yang baku tidak banyak menggunakan bahasa asing.

Kelebihan yang dimiliki pengarang Sari Safitri mohan adalah di dalam karya ini yaitu dari segi stilistik yang menarik, mengungkapkan setiap kejadian secara sistematis, terarah dan kronologis, sehingga penulis tertarik untuk mengkaji masalah-masalah yang terdapat di dalam novel tersebut.

Penelitian ini akan menganalisis novel dengan mengfokuskan Konflik-konflik yang terjadi di dalam novel penari kecil, yaitu konflik batin terkait sikap ayah terhadap anak.

Secara umum konflik menurut Jonathan Turner (2007:80-81) teori konflik merupakan proses terjadinya konflik di dalam sebuah sistem sosial atau masyarakat. Pada akhirnya konflik terbuka antara kelompok-kelompok yang bertikai sangat tergantung pada kemampuan masing-masing pihak untuk mendefinisikan kepentingan mereka secara objektif dan untuk menangani, mengatur, dan mengontrol kelompok itu.

Untuk menganalisis novel penari kecil peneliti mengfokuskan pada konflik yang terdapat dalam novel tersebut, karena setelah membaca novel penari kecil karya Sari Safitri Mohan pembaca menemukan banyak konflik batin yang dapat dijadikan pembelajaran manusia untuk lebih baik. Konflik dan psikologi merupakan salah satu yang penting dalam kehidupan manusia. Konflik batin dalam novel menarik dan perlu dianalisis melalui berbagai macam konflik yang terjadi dalam rangkaian kisah para tokohnya.

Tujuan penelitian ini adalah untuk memperoleh hasil deskripsi tentang konflik batin pada tokoh-tokoh dalam novel penari kecil karya sari safitri mohan terkait dengan tekanan, larangan-larangan dan peraturan-peraturan yang tak masuk akal.

Penelitian ini diharapkan memberi manfaat dalam berbagai hal sebagai berikut: 1) bagi peneliti, penelitian ini diharapkan dapat menambah pengetahuan, wawasan, serta dapat diaplikasikan dalam kehidupan nyata. 2) bagi pembaca sastra, novel adalah media untuk menambah wawasan dari pesan yang terdapat di dalamnya. 3) Bagi Masyarakat, dengan adanya penelitian ini diharapkan masyarakat mendapatkan informasi yang akurat terkait novel yang baik dalam memilih bahan bacaan untuk keluarga, sekaligus dapat meneladani nilai moral di dalamnya. 4) Bagi Guru Bahasa dan Sastra Indonesia, penelitian ini diharapkan dapat membantu para guru dalam memilih bahan ajar yang bermutu. Para guru juga diharapkan terbantu dalam memilih model analisis karya sastra dalam pembelajaran apresiasi sastra, khususnya novel yang dikaitkan dengan nilai moral.

\section{TEORI KONFLIK}

menurut Jonathan Turner (2007:80-81) teori konflik merupakan proses terjadinya konflik di dalam sebuah sistem sosial atau masyarakat. Pada akhirnya konflik terbuka antara kelompok-kelompok yang bertikai sangat tergantung pada kemampuan masing-masing pihak untuk mendefinisikan kepentingan mereka secara objektif dan untuk menangani, mengatur, dan mengontrol kelompok itu. Turner juga memusatkan perhatiannya pada konflik sebagai suatu proses dari 
peristiwa-peristiwa yang mengarah pada interaksi yang disertai kekerasan antara dua pihak atau lebih, ia menjelaskan sembilan menuju konflik terbuka.( Dalam Raho, 2007:80-81)

Menurut Turner (1975: 194) yaitu (1) sistem sosial terdiri dari unit-unit atau kelompok-kelompok yang saling berhubungan satu sama lain, (2) di dalam unitunit atau kelompok-kelompok itu terdapat ketidak seimbangan pembagian kekuasaan atau sumber-sumber penghasialan, (3) unit-unit atau kelompokkelompok yang tidak berkuasa atau tidak mendapat bagian dari sumber-sumber pengahasialan mulai mempertanyakan legitimasi sistem tersebut, (4) pertanyaan legitimasi itu membawa mereka kepada kesadaran bahwa mereka harus mengubah sistem alokasi kekuasaan atau sumber-sumber penghasilan itu demi kepentingan mereka, (5) kesadaraan itu menyebabkan mereka secara emosional terpancing untuk marah, (6) kemarahan tersebut meledak begitu saja yang tidak terorganisir, (7) keadaan yang demikian menyebabkan mereka semakin tegang, (8) ketegangan yang semakin hebat menyebankan mencari jalan untuk terorganisir diri guna melawan kelompok yang berkuasa, (9) akhirnya konflik terbuka bisa terjadi anatara kelompok yang berkuasa dan tidak berkuasa, tingkat kekerasan didalam konflik itu tegantung kepada kemampuan masing-masing pihak yang bertikai untuk mendefinisikan kembali kepentingan mereka secara obyektif atau kemampuan masing-masing pihak untuk menangani, mengantur dan mengontrol konflik itu (Dalam Raho, 2007: 80-81).

Teori konflik yang dikemukakan oleh Lewis Coser (2007:82) teori ini menekankan fungsi konflik bagi sistem sosial atau masyarakat. Lewis memusatkan perhatiannya pada fungsi-fungsi dari konflik, konflik bersifat funsional dan terarah kepada pengintegrasian teori konflik dan teori funsional. Misalnya penekanan yang tidak terlalu banyak terhadap peraturan bisa menimbulkan tidak kestabilan dan sekalipun menekankan peraturan yang ketat bisa menimbulkan ketidak stabilan didalam masyarakat. (Dalam Raho, 2007:82).

\section{METODE PENELITIAN}

Penelitian dengan judul konflik batin terkait sikap ayah terhadap anak padan novel penari kecil karya sari safitri mohan termasuk penelitian kualitatif.

Penelitian ini dikatakan kualitatif karena memenuhi karakteristik penelitian kualitatif, diantaranya 1) berlatar ilmiah; 2) analisis data induktif; 3) deskriptif; 4) mementingkan proses dari pada hasil.

Penelitian ini berjenis kualitatif dan diuraikan secara deskriptif, maka metode yang digunakan ialah metode pustaka dan metode dokumentasi. Metode pustaka digunakan untuk mengambil data atau bahan dari pustaka yang terdapat di perpustakaan, sedangkan metode dokumentasi merupakan pengumpulan data melalui dokumen, tulisan, atau media cetak.

Dilihat dari isi atau permasalahan yang diteliti, pendekatan yang digunakan dalam penelitian ini adalah pendekatan psikologi sastra. Data dalam penelitian ini adalah data deskriptif yang berupa kata, kalimat, ungkapan, yang mengandung konflik batin, peraturan yang tak masuk akal, kekangan dan larangan-larangan yang membuat anak-anak tak bisa berekspresi sesuai dengan usia mereka.

Langkah-langkah yang ditempuh dalam analisis data penelitian ini adalah sebagai berikut: membaca dengan cermat novel penari kecil karya Sai Safitri Mohan dengan menggunakan pendekatan psikologi sastra guna memahami 
kembali data yang sudah diperoleh, menginterpretasi data yang terkait dengan teori konflik yang telah ditentukan dalam pengelompokan, menganalisis dan mendeskripsikan data yang terjadi dengan konflik yang terkait dengan sikap ayah terhadap anak dalam novel penari kecil, menganalisis dan mendeskripsikan konflik batin terkait sikap ayah terhadap anak pertama (Intan), konflik batin terkait sikap ayah terhadap anak kedua (Ira), konflik batin anak pertama (Intan) terhadap ayah, konflik batin anak kedua (Ira) terhadaap ayah.

\section{HASIL PENELITIAN}

Berdasarkan hasil penelitian novel penari kecil karya Sari Safitri Mohan ditinjau dari psikologi sastra, peneliti menemukan hasil diantaranya seperti diuraikan di bawah ini.

\section{Konflik Batin Terkait Sikap Ayah Terhadap Anak Pertama (Intan)}

Dalam novel penari kecil karya Sari Safitri Moha ayah menutut anak-anak nya untuk menjadi nomor satu dan menuntut harus sukses seperti ayah nya, didikan yang keras membuat mereka harus bekerja keras untuk membuktikan bahwa Intan bisa, dan Intan sebagai anak pertama hanya bisa menurut perintah sang ayah.

Tak ada toleransi atas kesalahan kecil, semua harus benar dari awal hingga akhir.Semua harus benar dari titik koma, intan harus jadi anak terbaik dalam segala hal. Jika ia gagal papa akan menghujaninya dengan kemarahan. “ apanya yang begitu sulit dari matematika sampai kau harus dapat nilai tujuh" begitu Tanya papa (Mohan, 2013:22).

Dari kutipan diatas menjelaskan bahwa sang ayah mewajibkan anak-anak nya harus menjadi yang terbaik, semua harus tertata dan harus perfeks. Dari kutipan diatas sudah terlihat bahwa si anak ada beban psikologis yang berat karena sikap ayah yang begitu menekankan terutama dalam hal pelajaran

\section{Konflik Batin Terkait Sikap Ayah Terhadap Anak Kedua (Ira) Novel Penari Kecil}

Cita-cita setiap anak berbeda-beda walaupun satu darah, kesenangan membuat mereka belajar dari yang tidak bisa menjadi bisa, dari yang tidak tahu menjadi tahu, tetapi berbeda dengan kehidupan (Ira) papanya terlalu memaksakan kehendaknya dengan cara memaksa anak-anaknya masuk kuliah dengan jurusan ekonomi karena papanya ingin semua anaknya bekerja kantoran, namun (Ira) lebih memilih menari karena menari sudah menjadi bagian dari jiwanya, menari membuat (Ira) melupakan semua hal dan masalah-masalah, aturan-aturan dan larangan-larangan yang dibuat papa.

Ira nggak suka matematika pa, ira nggak mau berurusan dengan semua yang berhubungan dengan angka atau rumus-rumus memusingkan,"jawabku kukuh. Papa memandangku tajam, aku tahu ia sudah mulai kesal."

" Mau jadi apa kamu dengan tarimu?"

" Jadi penari. Ira mau melestarikan budaya tari Indonesia pa."

“ Nggak ada anak cerita nya anak papa jadi penari, kerjalah di bank atau insinyur. Uang nya jelas ada, kamu nggak akan kesulitan hidup nanti, lebih ada gunanya secara langsung buat kamu. 
" Jadi menurut papa, menari itu nggak ada gunanya," sesuatu yang kucintai dilempar begitu saja oleh papa, tidak dianggap sebagai sesuatu yang patut ku banggakan" (Mohan, 2013:101).

Hobinya menari membuat ia bisa memutuskan hal yang terbaik menurutnya, termasuk menolak pendapat sang ayah yang menyusuhnya menjadi Insinyur dan bekerja bank/ kantoran yang menurut sang ayah ittu lbih baik untuk masa depan ketimbang menari, menurut ayah menari tidak memberikan hal yang positif. Ayah ingin semua anak-anak nya bekerja dikantoran

\section{Konflik Batin Anak Pertama (Intan) Terhadap Ayah dalam Novel Penari \\ Kecil.}

Novel Penari kecil arya Sari Safitri Mohan Seperti dalam teori Schellnberg (1997:18) yang mengatakan bahwa superego merupakan suara isi hati atau kata hati, seperti kutipan dibawah ini menunjukkan bahwa ada konflik yang mempengaruhi ego yang tinggi antara anak dan ayah.

" Aku mau pulang, tapi nggak mau di ceramahi papa."

" papa kan suka ceramah, udah terima aja."

" nggak mau, aku nggak mau pulang, kalau di bentak-bentak dan di ceramahi lagi."

“Kamu nic, udah salah, masih pula gengsi.'

“Kayak kamu nggak aja.” (Mohan, 2013:153)

Ada sedikit rasa marah kepada papa karena selama ini Intan hidup dengan tekanan, aturan dan larangan yang tak masuk akal dan tak wajar bagi mereka karena mereka mempunyai dunia yang indah, ia tidak mau pulang sebelum papa berjanji tidak akaan memarahi dan membentak-bentak intan lagi.

\section{Konflik Batin Anak Kedua (Ira) Terhadap Ayah pada Novek Penari Kecil}

Pada Novel Penari Kecil ini Ira suka sekali menari, Menari adalah pekerjaan Ira, ia dengan suka relanya mengajar teman-temannya untuk menari.

"Papa tidak kumintai ijin sebelumnya, aku tidak mau dilarang lagi.

Kuperkenalkan saja satu-satu mereka pada papa dan kubillang bahwa kami semua akan berlatih untuk festival tari kreasi modern seprovinsi”.

Ketika Ira menari dan mengajari teman-temannya menari. Ira tidak meminta ijin kepada papa kerena ia tidak mau lagi dilarang dan diatur untuk kegiatan menari. Ketika papa bertanya ia hanya menjawab ada latihan menari untuk acara festival tari kreasi modern seprovinsi dan detik itu pula Ira memperkenalkan teman-temannya kepada papa yang saat itu berada dalam kamar Ira.

\section{PEMBAHASAN}

Berdasarkan data-data yang terkumpul hasil dari temuan penelitian pembahasan dalam penelitian bahwa pada Novel Penari Kecil Karya Sari Safitri Mohan ini banyak membawa maanfaat bagi kehidupan kita, bahwa kelak kita menjadi orangtua harus mengikuti zaman dan tidak harus menjadi orangtua yang kolot untuk anak-anaknya. Seperti dalam Novel Penari Kecil ini menunjukkan keegoisan orangtua demi didikan yang baik untuk anak-anaknya, dalam Novel Penari Kecil ini papa diibaratkan sebagai Id karena ia memiliki jiwa penguasa, harus dihormati, sewenang-wenangnya dan mementingkan diri sendiri. Id cocok 
dengan karakter papa yang bertindak seenaknya mengatur semua urusan putriputri nya, termasuk urusan asmara pun juga diatur, aturan-aturan yang tidak masuk akal pun ia buat, kedua putri nya mengalami tekanan batin akibat dari kesalahan papanya. Sedangkan Ego cocok dengan karakter (Intan), (Intan) mengalami tekanan batin yang kuat sehingga terkadang hal yang dilakukan tidak wajar seperti kawin lari. Dan Superego cocok dengan karakter (Ira). Walaupun Ira juga mengalami depresi akibat tekanan dan aturan yang tak masuk akal di luar maupun di dalam rumah tapi ia masih tetap melakukan sesuatu dengan tindakan wajar dan berpikir panjang sebelum melakukan sesuatu.

Kedua anaknya merasa tertekan akan semua aturan dan larangan-larangan yang ada dirumah, mereka berdua (Intan dan Ira) tidak pernah merasa nyaman berada didalam rumah, segala hal yang mereka kerjakan harus mendapat izin dari papanya begitu pun dengan kesenangan yang mereka jalani. Kesenangan menari Ira tak pernah mendapat restu dari papanya namun (Ira) tetap menjalani kesenangan nya walaupun dengan terpaksa harus bersembunyi dari papanya.

Teori kepribadian psikologi sastra meliputi id, ego dan super ego. Id berlaku seperti penguasa absolut, harus dihormati, manja, sewenang-wenang, dan mementingkan diri sendiri, apa yang diinginkan harus segera terlaksana. Sedangkan Ego diibaratkan memiliki tugas harus menyelesaikan segala pekerjaan yang terhubung dengan realitas dan tanggap terhadap keinginan masyarakat. Dan Superego diibaratkan sebagai pendeta yang selalu penuh pertimbangan terhadap nilai-nilai baik dan buruk.

Papa membatasi semua kegiatan aktivitas anak-anaknya diluar rumah. Larangan dan aturan yang mereka dapat membuat mereka berdua mengalami tekanan batin tersendiri, masa remaja mereka tidak perna mendapat kebebasan untuk berkumpul dengan teman-teman yang seumur dengan mereka, (Intan) dan (Ira), (Ira) hanya bisa mengiyahkan aturan-aturan itu, Intan diharuskan masuk kuliah dengan jurusan Fakultas Ekonomi, jurusan ini sengaja dipilihkan papanya agar kelak Intan dapat bekerja dikantoran atau bisa meneruskan usaha keluarga, Intan hanya bisa mengiyakan atas semua yang dipilihkan untuk (Intan), begitu pun masalah pria, (Intan) tidak benar-benar berani mengenalkan pria idaman kepada papanya dan pada akhirnya ketakutan (Intan) pun menjadi kenyataan, hubungan asmara mereka tidak perna mendapat restu dari orangtua (Intan), hingga pada akhirnya mereka berdua nekat untuk pergi dari rumah dan melakukan kawin lari. Sebenarnya kedua orangtua (Intan) hanya ingin (Intan) anak pertamanya mendapatkan laki-laki yang bertanggug jawab bukan seperti Rudi, ia laki-laki yang tidak bertanggung jawab. Pemberontakan (Intan) dengan sikap dan perlakuan yaitu kawin lari nya mereka berdua. Hal yang sama pun terjadi pada anak kedua nya yaitu (Ira), (Ira) pun mengalami hal yang sama seperti (Intan), (Ira) juga mendapat masukan dan arahan oleh papanya agar masuk kuliah di Fakultas Ekonomi agar kelak mereka bisa bekerja di Bank atau di kantoran, namun (Ira) berbeda dengan (Intan), (Ira) bisa melakukan apapun hal yang disukai dan tidak disukai, ia lebih senang memilih Fakultas seni.

Papa adalah seorang sosok laki-laki yang dapat menjadi panutan buat kita, (Intan) dan (Ira) masih mengalami gejolak batin, kegelisahan batin akibat dari aturan yang dibuat papa namun (Ira) mempunyai banyak ide untuk dapat mengatasi itu, ia berkumpul dengan teman seumur mereka, (Ira) mengambil alasan dengan adanya les menari dari sekolahnya, namun berbeda dengan (Intan), 
kakak kandung dari (Ira) ini hanya bisa pasrah dengan aturan yang dibuat papa, setelah selesai sekolah (Intan) langsung pulang, waktu berjalan lama pada akhirnya (Intan) juga memilih untuk les piano sepulang sekolah, jadi mereka berdua memiliki hobi masing-masing yang mereka jalani sepulang sekolah, tetapi jam pulang sekolah masih dibatasi oleh papanya. Dengan berjalannya waktu (Intan) menjadi sukses ia meneruskan usaha keluarga, sedangkan (Ira) menjadi Guru Tari disuatu Lembaga. Kesuksesan mereka tak lepas dari peran seorang ayah.

\section{SIMPULAN}

Novel Penari Kecil karya Sari Saftri Mohan merupakan novel yang sangat bagus sebagai pembelajaran terutama dari segi psikologi nya. Untuk membentuk suatu simpulan yang utuh dan bulat diperlukan suatu analisis yang terinci secara panjang lebar dan mendetail. Kebulatan simpulan merupakan hasil akhir yang secara menyeluruh mencakup dari analisis yang telah disusun oleh penulis. Berdasarkan data-data yang terkumpul hasil dari temuan penelitian pembahasan dalam penelitian maka dapat ditarik simpulan bahwa pada Novel Penari Kecil Karya Sari Safitri Mohan ini banyak membawa maanfaat bagi kehidupan kita, bahwa kelak kita menjadi orangtua harus mengikuti zaman dan tidak harus menjadi orangtua yang kolot untuk anak-anaknya. Seperti dalam Novel Penari Kecil ini menunjukkan keegoisan orangtua demi didikan yang baik untuk anakanaknya, dalam Novel Penari Kecil ini papa diibaratkan sebagai Id karena ia memiliki jiwa penguasa, harus dihormati, sewenang-wenangnya dan mementingkan diri sendiri. Id cocok dengan karakter papa yang bertindak seenaknya mengatur semua urusan putri-putri nya, termasuk urusan asmara pun juga diatur, aturan-aturan yang tidak masuk akal pun ia buat, kedua putri nya mengalami tekanan batin akibat dari kesalahan papanya.

\section{SARAN}

Novel Penari Kecil sangat baik untuk bahan pembelajaran, baik di tingkat sekolah menengah pertama, sekolah menengah atas, maupun perguruan tinggi. Para guru dan dosen diharapkan berkenan memakai novel ini sebagai materi pembelajaran bahasa dan sastra Indonesia, apresiasi sastra, kritik sastra, serta berbagai kajian sastra yang memanfatkan novel sebagai sumber materinya. Dari novel ini diharapkan para siswa dan mahasiswa terinspirasi terhadap semangat yang ada pada tokoh-tokoh didalam Novel Penari Kecil.

\section{DAFTAR PUSTAKA}

Budiyono, Catur Sunu, dkk. 2015. Pedoman Penulisan Skripsi dan Artikel Ilmiah. Surabaya: University Press FKIP Adi Buana Surabaya.

Raho, Bernard. 2007. Teori Sosiologi Modern. Jakarta: Prestasi Pustaka Publisher.

Safitri, Mohan, Sari. 2013. Penari Kecil. Jakarta: PT Gramedia pustaka utama. 